\title{
PERANAN KEPALA SEKOLAH DALAM MENINGKATKAN MUTU DAN KOMPETENSI GURU AGAMA HINDU DI SEKOLAH DASAR
}

\author{
Oleh \\ Ni Kadek Yeni Nurmawati, I Wayan Mandra \\ Institut Hindu Dharma Negeri Denpasar \\ mandra@ihdn.ac.id
}

Diterima 10 Juli 2018, direvisi 31 Juli 2018, diterbitkan 31 Agustus 2018

\begin{abstract}
The era of globalization has an impact on the emergence of intense competition in various sectors such as; in the field of science and technology, economics and others. Competition in maintaining or competing for various sectors requires the existence of competent human beings in order to continue to exist in the midst of socio-cultural changes and the rapid development of science and technology. Speaking of the quality of education, the education component is certainly a central point which will affect the quality of education produced. One component of education in question is the existence of teachers or educators.

Principals play an important role in increasing teacher motivation and competence in schools. The failure of school principals to create effective and efficient learning conditions will have an impact on the future of students, often educators are also used as "scapegoats", whereas other aspects such as problems in budget constraints, low attention to teachers, supervision of the curriculum, education regulations contribute low quality of education.
\end{abstract}

\section{Keywords: Kepala Sekolah, Meningkatkan Mutu, Guru Agama Hindu}

\section{PENDAHULUAN}

Era globalisasi berdampak terhadap timbulnya persaingan yang ketat dalam berbagai sektor seperti; di bidang IPTEK, ekonomi dan lain-lain. Persaingan dalam mempertahankan atau memperebutkan berbagai sektor tersebut menghendaki adanya manusia-manusia yang mampu berkompetensi agar tetap eksis di tengah perubahan sosial budaya dan IPTEK yang demikian pesat perkembangannya. Hanya manusia unggul dan berkualitas yang akan mampu menghadapi persaingan dalam pasar bebas. Hal ini juga berarti bahwa, era globalisasi dengan berbagai konsekuensinya memerlukan sumber daya manusia yang berkualitas, profesional, kompetitif, serta memiliki ketrampilan dan kompetensi yang sesuai dengan tuntutan pasar kerja. 
Semua kompetensi itu diperlukan agar mampu bersaing di tengah perubahan masyarakat serta dapat memanfaatkan teknologi informasi dan komunikasi untuk kemajuan manusia. Ketidakmampuan dalam beradaptasi di tengah perkembangan IPTEK yang berkembang pesat dapat dinyatakan sebagai "Cultural Lag",yang merupakan kemajuan ilmu pengetahuan dan teknologi yang pesat sebagai manifestasi dari produk budaya yang tidak diimbangi oleh kemampuan sumber daya manusia untuk menggunakan produk budaya tersebut.

Untuk menghindarkan adanya gap dalam bentuk cultural lag dan multy efect dari kemajuan IPTEK, diperlukan campur tangan negara dalam pembangunan dibidang pendidikan, sebab peran negara tidak dapat dipisahkan dalam proses pendidikan. Berbagai pakar pendidikan telah mengupas masalah ini sejak Plato maupun pakar-pakar pendidikan dalam kehidupan negara-negara modern. Negara merupakan suatu unit berdasarkan kekuasaan. Dalam upaya untuk melestarikan kekuasaannya, negara telah menjadikan pendidikan sebagai sarana untuk mencapai tujuan tersebut. Hal inilah yang telah dikupas antara lain oleh Michael A. Apple di dalam bukunya yang terkenal Education and Power (1985). Demikian pula dalam kehidupan bernegara tersangkut dalam pelestarian kekuasaan negara melalui politik kebudayaannya (cultural politics). Michael W. Apple dalam Tilaar (2002: 79) menjelaskan bahwa politik kebudayaan suatu negara disalurkan melalui lembaga-lembaga pendidikannya. Oleh sebab itu, dalam pendidikan tersalur kemauan-kemauan politik atau sistem kekuasaan dalam suatu masyarakat. Biasanya, hal tersebut tidak disadari dalam sistem pendidikan dari suatu masyarakat, namun demikian kekuasaan politik secara tidak langsung berada dan merasuk dalam sistem pendidikan dengan bentuk "hidden curriculum". Tanpa disadari suatu sistem pendidikan melaksanakan citacita suatu negara, mau atau tidak mau, sadar atau tidak sadar.
Berbicara masalah kualitas pendidikan, komponen pendidikan tentunya menjadi titik sentral yang nantinya akan berpengaruh terhadap kualitas pendidikan yang dihasilkan. Salah satu komponen pendidikan yang dimaksud adalah eksistensi guru atau tenaga pendidik. Dalam usaha meningkatkan kualitas sumber daya manusia pendidikan, guru merupakan komponen strategis dalam mengembangkan sumber daya manusia yang dibina dan dikembangkan terus menerus. Hal ini dimaksudkan agar di dalam menjalankan profesinya, guru dapat melaksanakan tugas sesuai dengan otoritas atau tanggung jawab yang dibebankan kepadanya. Dalam hal ini perlu adanya koordinasi secara berkesinambungan antara semua perangkat pendidikan yakni guru, kepala sekolah, pengawas dan stake holder (pengelola pendidikan). Kepala Sekolah merupakan komponen yang penting dalam pengelolaan dan penyelenggaraan pendidikan untuk menjamin mutu pendidikan melalui pengawasan bidang perencanaan, pelaksanaan dan evaluasi dalam pendidikan di sekolah. Mutu pendidikan yang baik akan menentukan lahirnya generasi penerus bangsa yang mampu. Untuk menjamin kualitasnya, proses pendidikan perlu diawasi.

Sejalan dengan peran dan tanggung jawab kepala sekolah seperti yang diuraikan di atas, maka kepala sekolah memiliki peran yang strategis dalam meningkatkn sumber daya manusia, melalui proses pembelajaran di sekolah. Guru merupakan sumber daya yang dibina dan dikembangkan terus-menerus, agar dapat melakukan tugas profesinya. Di samping itu kepala sekolah memberi motivasi kepada guru-guru untuk terus belajar menyesuaikan diri dengan perkembangan ilmu pengetahuan dan teknologi serta mobilitas masyarakat (Porwas, 2004: 4).

Mengenai bagaimana kepala sekolah dalam memberikan motivasi, maka dalam hal ini diperlukan pemahaman kepala sekolah 
terhadap esensi motivasi. Menurut (Steiner dalam Winardi 2002: 14) motivasi adalah keadaan di dalam diri yang mendorong atau menggerakkan para individu. Dengan demikian, tanpa motivasi tidak akan ada tujuan dan tingkah laku yang diorganisasikan oleh individu baik di tempat kerja maupun di luar tempat kerja. Motivasi dapat diartikan sebagai usaha pemberian dorongan pada seseorang agar mau berbuat sesuatu. Motivasi dalam individu menyebabkan seseorang melakukan kegiatan tertentu untuk mencapai tujuan yang tertentu pula. Dengan demikian, motivasi kerja adalah serangkaian usaha untuk menyediakan kondisi instrinsik dan ektrinsik sehingga seseorang mau bekerja sesuai dengan harapan. Sehubungan dengan hal tersebut, guna mendorong motivasi dan prestasi kerja guru perlu didukung oleh berbagai kondisi seperti: gaji yang memadai dan layak, mempunyai tanggung jawab yang tinggi, mempunyi dedikasi yang tinggi, mencintai profesinya, bekerja karena panggilan hati nurani, serta adanya reward atau penghargaan sesuai prestasi yang diraih, dan adanya hubungan yang harmonis antara kepala sekolah dengan guru, dan adanya iklim yang kondusif untuk menjalankan profesi.

Motivasi kerja akan dapat ditingkatkan apabila ada faktor-faktor intensif yang bersifat internal dan eksternal yang memungkinkan terwujudnya suatu tindakan yang kondusif dan mengarah kepada tercapainya unjuk kerja yang optimal. Motivasi juga akan dapat mendorong terwujudnya prestasi yang diharapkan setelah terpenuhinya kebutuhan-kebutuhan yang diharapkan. Hal ini dapat dimaklumi mengingat setiap orang mempunyai kebutuhan tertentu dan mengharapkan pemenuhan atas kebutuhan-kebutuhan tersebut. Zinun (1984: 72) menganjurkan agar usaha positif untuk memotivasi dapat meningkatkan kinerja hendaknya dilakukan dengan pengawasan yang tidak terlalu ketat dan kaku terhadap guru/pegawai dengan memberikan kesempatan yang cukup untuk berprakarsa dalam melaksanakan tugasnya.
Selanjutnya penghargaan terhadap hasil kerja yang gemilang dari seseorang dapat dilakukan dengan berbagai cara seperti : memberikan pujian, tanda penghargaan, hadiah dalam bentuk material dan non material. Kerja yang tinggi dimanifestasikan pada kreativitas dan inisiatif dalam kerja sehari-hari. Kerja yang tinggi dapat meningkatkan produktivitas kerja (Nawawi \& Handari, 1990: 21). Produktivitas kerja dipengaruhi pula adanya berbagai permasalahan yang berkaitan dengan kondisi guru, antara lain : (1) adanya keragaman kemampuan guru dalam proses pembelajaran dan penguasaan pengetahuan, (2) belum adanya alat ukur yang akurat untuk mengetahui kemampuan guru, (3) pembinaan yang dilakukan belum mencerminkan kebutuhan, (4) kesejahteraan guru yang belum memadai, (5) kebijakan pemerintah dalam bidang pendidikan agama masih bersifat dikotomi (masih ada unsur mayoritas dan minoritas), sehingga hal ini dapat mempengaruhi motivasi dan prestasi kerja.

Terkait dengan fenomena yang muncul dalam masalah pendidikan, seringkali pendidik dijadikan "kambing hitam". Padahal aspek-aspek lain seperti masalah keterbatasan anggaran, rendahnya perhatian terhadap guru, pengawasan, kurikulum, regulasi pendidikan dan lain-lain turut menyumbang terhadap rendahnya mutu pendidikan. Sehingga wacana tentang perbaikan dan pembaharuan dalam bidang pendidikan dan pengajaran sering diperdengarkan, namun tidak dibarengi dengan pembuatan perencanaan yang matang dan sistematis bahkan konsep-konsep pemecahan masalah perbaikan pendidikan dan pengajaran belum terwujud.

Kepala sekolah tidak hanya mengelola sekolah dalam makna statis, melainkan menggerakkan semua potensi yang berhubungan langsung atau tidak langsung bagi kepentingan proses pembelajaran siswa. Kegagalan kepala sekolah menciptakan kondisi pembelajaran yang efektif dan efisien akan berdampak pada mutu prestasi dan masa depan peserta didik. Semua komunitas sekolah memerlukan bimbingan dan 
pembinaan dari kepala sekolah dalam upaya mewujudkan proses belajar yang efektif (Sudarwan Danim, 2009: 13).

Menurut Undang - Undang RI No. 20 Tahun 2003 Bab XI Pasal 40 ayat (1) pendidik dan tenaga kependidikan berhak memperoleh : (a) penghasilan dan jaminan kesejahteraan sosial yang pantas dan memadai, (b) penghargaan sesuai dengan tugas dan prestasi, (c) pembinaan karier sesuai dengan tuntutan pengembangan kualitas, (d) perlindungan hukum dalam melaksanakan tugas dan hak atas hasil kekayaan intelektual, (e) kesempatan untuk menggunakan sarana, prasarana dan fasilitas pendidikan untuk menunjang kelancaran pelaksanaan tugas. Jadi yang dimaksud kompetensi guru adalah suatu ukuran penguasaan pengetahuan dan perilaku bagi seorang guru agar berkelayakan untuk menduduki jabatan fungsional sesuai bidang tugas dan kualifikasi jenjang pendidikan.

Berdasarkan latar belakang yang dikemukakan, maka masalah dalam penelitian ini dapat diidenfikasikan berupa faktor motivasi terhadap upaya guru dalam meningkatkan kompetensi dalam mengajar di Sekolah Dasar Saraswati 6 Denpasar yang mencakup faktor internal dan faktor eksternal. Faktor internal adalah faktor yang berasal dari diri guru itu sendiri yang meliputi kemampuan, kesiapan, sikap, minat dan intelegensi. Dalam penelitian ini hanya dibatasi pada faktor eksternal yaitu variabel peran kepala sekolah dalam meningkatkan motivasi dan kompetensi guru agama Hindu di Sekolah Dasar Saraswati 6 Denpasar, dengan alasan kepala sekolah berfungsi strategis bagi para guru agama untuk meningkatkan kualitas pembelajaran di bidang agama.

\section{METODE}

Penelitian ini menggunakan jenis penelitian kualitatif yang menghasilkan data deskriptif berupa kata - kata tertulis atau lisan dari orang - orang dan perilaku yang dapat diamati. Sumber data adalah guru-guru Agama Hindu, sedang obyek penelitian adalah guru Agama Hindu di Sekolah Dasar Saraswati 6 Denpasar. Metode penentuan informan dalam penelitian ini adalah teknik porposive sampling yaitu penentuan sampel yang didasarkan kepada tujuan tertentu yang ingin dicapai. Dalam hal ini adalah untuk memperoleh informasi tentang peranan kepala sekolah dalam meningkatkan mutu dan kompetensi guru agama Hindu di Sekolah Dasar Saraswati 6 Denpasar. Metode pengumpulan data yang digunakan dalam penelitian kualitatif adalah metode seperti : (1) Observasi, (2) Wawancara (interview), (3) Dokumentasi.

Hasil dan Pembahasan

\section{Peranan Kepala Sekolah dalam Meningkatkan Motivasi dan Kompetensi Guru Agama Hindu di Sekolah Dasar Saraswati 6 Denpasar}

Berdasarkan hasil observasi di lapangan peran kepala sekolah sudah sesuai dengan program yang direncanakan yaitu bersifat sistematis yang artinya melaksanakan pengawasan secara teratur, berencana dan kontinyu. Pengawasan yang dilakukan selalu bertujuan untuk menemukan atau mengidentifikasi kemampuan dan ketidakmampuan personil untuk memberikan bantuan/layanan kepada personil tersebut guna meningkatkan kemampuan/keahliannya. Sasaran pengawasan yang dilakukan sebagai usaha peningkatan hanya ditujukan kepada guru atau personil pendidikan lainnya.

Tujuan dilakukan pengawasan kepada guru-guru agama Hindu di Sekolah Dasar yang dilakukan oleh kepala sekolah adalah untuk memberikan layanan dan bantuan kepada guru-guru untuk mengembangkan situasi belajar mengajar yang dilakukan oleh guru di kelas. Sasaran yang diinginkan dalam pelaksanaan pengawasan adalah : (1) pengembangan kurikulum yang sedang dilaksanakan di sekolah, (2) peningkatan 
proses belajar mengajar, (3) pengembangan potensi seluruh staf di sekolah. Dalam proses pelaksanaan pengawasan, seorang kepala sekolah selalu bersifat otokrat dan korektif dan menjadi sikap yang konstruktif dan kreatif untuk menstimulasi guru sehingga mereka merasa tumbuh bersama.

Sergiorani (dalam Perni, 2005:38) mengemukakan tugas kepala sekolah meliputi : pengawasan, perencanaan, mengambil keputusan, organisator, koordinator, komunikator, motivator dan evaluasitor, di mana semua tugas tersebut dilaksanakan dalam program sekolah. Sehingga dapat disimpulkan bahwa keberhasilan suatu sekolah tidak terlepas dari peran kepala sekolah dalam melaksanakan tugasnya.

Dari hasil wawancara yang dilakukan kepada guru-guru agama Hindu di Sekolah Dasar Saraswati 6 Denpasar bahwa pengawasan yang dilaksanakan oleh kepala sekolah adalah mencakup tentang kegiatan bimbingan yang ditujukan kepada guru untuk memperbaiki kondisi-kondisi baik personil maupun material yang memungkinkan terciptanya situasi belajar (pembelajaran) yang lebih baik, untuk tercapainya tujuan pendidikan.

Pengawasan yang dilakukan oleh kepala sekolah dalam meningkatkan motivasi dan kompetensi di Sekolah Dasar Saraswati6 Denpasar menggunakan teknik-teknik pengawasan yang bersifat individual yaitu : kunjungan kelas, observasi kelas, percakapan pribadi, saling mengunjungi kelas dan menilai diri sendiri. Misalnya : kunjungan kelas yang dilakukan oleh kepala sekolah biasanya dengan cara datang ke kelas pada saat guru sedang mengajar dan mengadakan peninjauan langsung kelas.

Sebagaimana yang dikatakan oleh Nurtain (1990) bahwa keakraban dapat memelihara suasana kerja yang menggembirakan, bersemangat dan dapat menumbuhkan optimisme dalam setiap individu. Dalam konteks ini kepala sekolah diharapkan dapat membina suasana keakraban antara anggota (guru-guru), penuh kebersamaan dan menyenangkan dari orangorang yang ada dalam organisasi.
Tujuan dari teknik kunjungan kelas dilakukan adalah : (1) membantu guru yang belum berpengalaman, (2) membantu guru yang sudah berpengalaman tentang kekeliruan yang dia lakukan, (3) membantu guru pindahan yang belum jelas tentang situasi dan kondisi kelas yang diajarnya. Selain kunjungan kelas secara individu yang dilakukan oleh kepala sekolah, Suwimba Astawa juga menyampaikan bahwa kepala sekolah mengadakan observasi kelas bertujuan untuk memperoleh data tentang segala sesuatu yang terjadi di dalam proses belajar mengajar. Data ini sebagai dasar bagi kepala sekolah melakukan pembinaan terhadap guru yang akan membawa para guru ke arah yang lebih baik.

Mulyadi (dalam Perni, 2005: 46) menyatakan bahwa pembinaan hubungan kerja antara atasan dan bawahan harus dilaksanakan dengan sebaik-baiknya. Terjalin hubungan yang baik antara atasan dengan bawahan akan membawa keberhasilan dalam melaksanakan tugas yang telah ditetapkan.

Selanjutnya Mardika (wawancara tanggal 7 Juni 2010) menyampaikan peran kepala sekolah diharapkan mampu membantu guru dalam hal :

1. Kepala sekolah diharapkan dapat mengarahkan guru dalam pelaksanaan pengajaran sehingga siswa, guru, tempat dan bahan pengajaran sesuai dengan waktu yang disediakan serta tujuan instruksional yang ditetapkan.

2. Diharapkan dapat membantu dalam pemenuhan fasilitas sesuai dengan rancangan proses belajar mengajar.

3. Diharapkan dapat membantu guru dalam merencanakan dan mengimplementasikan dalam meningkatkan pengalaman belajar dan unjuk kerja guru dalam melaksanakan pengajaran, yang meliputi bantuan dalam menyelenggarakan workshop, konsultasi, wisata karya, serta berbagai macam latihan dalam jabatan.

4. Memberikan informasi tentang pelaksanaan orientasi tentang suatu tugas atau cara baru dalam proses belajar mengajar. Karena guru perlu dilengkapi sarana dan prasarana dengan informasi 
yang relevan dengan tugas dan tanggung jawabnya.

Peran kepala sekolah di Sekolah Dasar Saraswati 6 Denpasar berperan sesuai dengan harapan guru dalam merencanakan pembelajaran, pelaksanaan kegiatan pembelajaran dan terhadap cara penilaian terhadap hasil siswa, hal ini sangat sejalan dengan teori Manajemen Pendidikan, semakin baik dan tinggi motivasi dari kepala sekolah terhadap guru-guru, maka kompetensi guru tersebut dalam mengajar akan termotivasi dan dengan lebih sering memberikan bimbingan dan dorongan, seperti memberi kesempatan kepada guru untuk berpendapat, menghargai guru sesuai kemampuan, memberi motivasi kepada guru untuk berkembang, lebih dipercaya dan didorong untuk mengembangkan diri, guru akan menjadi lebih meningkatkan kinerja dalam bertugas, terutama dalam meningkatkan motivasi dan kompetensinya. Senada dengan pendapat Perni (2005: 63) menyatakan bahwa kepala sekolah adalah sebagai orang yang menolong, menunjukkan ketegasan dan kehangatan, memberikan bimbingan, membangun hubungan saling mempercayai, memberikan penguatan, mendengarkan secara simpati serta menunjukkan sikap tanggap. Hal ini sangat sesuai dengan keinginan guru yang menyatakan bahwa motivasi adalah pekerjaan yang dilakukan oleh seorang pimpinan dalam memberikan inspirasi, semangat dan dorongan kepada orang lain, dalam hal ini guru untuk mengambil tindakan-tindakan. Pemberian dorongan ini bertujuan untuk memberikan semangat dan dapat mencapai hasil sebagaimana yang dikehendaki oleh guru agama Hindu khususnya guru agama Hindu di Sekolah Dasar Saraswati 6 Denpasar.

Lebih lanjut uraian Mardika (wawancara tanggal 7 Juni 2010) mengatakan bahwa, kepala sekolah dalam rangka pembinaan datang ke kelas untuk mengamati unjuk kerja guru dalam melaksanakan kegiatan belajar mengajar (KBM) karena untuk mengetahui lebih dekat suasana yang terjadi dalam melaksanakan KBM di kelas, dan untuk memotivasi kinerja guru agama Hindu dalam rangka meningkatkan mutu pendidikan dalam arti luas. Dalam melakukan pengawasan, kepala sekolah memberikan arahan dan bimbingan kepada guru agama Hindu dalam menyiapkan diri untuk proses belajar mengajar dan menuntun, membimbing serta mengarahkan guru untuk meningkatkan mutu pendidikan agama Hindu khususnya di sekolah dasar.

Sebagaimana yang dikatakan oleh Ariasa Giri (2007: 100) bahwa peranan kepala sekolah sebagai pengawas dilakukan dengan cara memberikan pengarahan dan bimbingan kepada guru dengan melakukan pembinaan sesuai dengan kekurangan-kekurangan yang dilakukan oleh para guru.

Lebih lanjut disampaikan oleh Mardika (wawancara tanggal 7 Juni 2010), bahwa dalam pengadaan perlengkapan sarana prasarana pembelajaran, kepala sekolah mencatat kekurangan sarana dan prasarana bagi guru dalam melaksanakan proses belajar dan mengajar, kepala sekolah menerima masukan dan saran dari guru tentang sarana prasarana yang diperlukan di sekolah untuk meningkatkan proses belajar mengajar, dan menyambut baik ide-ide guru dan model pembelajaran yang telah dikembangkan oleh guru dan memberikan kebebasan kepada guru dalam menerapkan metode baru dalam pembelajaran. Guru perlu menguasai berbagai jenis metoda sehingga dengan penggunaan metoda yang bervariasi, pengajaran lebih menarik dan tidak membosankan (Wiryawan, 1994: 49).

Jadi peran kepala sekolah disini adalah membimbing, membina guru berkewajiban mendukung (support) peningkatan pengajaran, berpartisipasi penuh dalam program pengajaran, mengkomunikasikan informasi kepada guru, mendorong para guru dan siswa untuk melaksanakan tugas mereka dengan baik.

Jadi semakin baik tingkat pengawasan yang dilaksanakan oleh kepala sekolah, motivasi dan kompetensi guru-guru dalam mengajar semakin baik, maka akan jelas peningkatan semangat siswa dalam belajar. Hal ini sesuai dengan harapan guru-guru 
Sekolah Dasar Saraswati 6 Denpasar, bahwa pengawasan yang dilakukan oleh kepala sekolah dalam memimpin guru-guru dan petugas yang lainnya dalam memperbaiki perkembangan-perkembangan guru-guru dan merevisi tujuan-tujuan pendidikan. Dengan adanya pengawasan dari kepala sekolah, guru untuk meningkatkan keterampilan mengajarnya sehingga dapat tercipta kondisi belajar mengajar yang efektif dan efisien.

Uraian diatas sesuai dengan teori manajemen pendidikan dimana seorang kepala sekolah mampu dan mempunyai keahlian dalam merencanakan pembelajaran, mengorganisasikan pembelajaran, memberikan motivasi kepada guru-guru dalam rangka meningkatkan kompetensinya, dalam pelaksanaan proses pembelajaran dikontrol agar sesuai dengan tujuan dan harapan yang diinginkan, selanjutnya mampu mengevaluasi, mengkoreksi atau merumuskan agar kegiatan yang sudah dilaksanakan sesuai dengan rencana yang telah diciptakan serta tujuan yang ingin dicapai.

\section{Hambatan-hambatan yang Dihadapi dalam Meningkatkan Motivasi dan Kompetensi Guru Agama Hindu di Sekolah Dasar Saraswati 6 Denpasar}

Berdasarkan wawancara dengan Mardika di Sekolah Dasar Saraswati 6 Denpasar bahwa hambatan-hambatan yang dihadapi dalam meningkatkan motivasi dan kompetensi guru agama Hindu di Sekolah Dasar Saraswati 6 Denpasar adalah tingkat kesejahteraan guru yang belum maksimal, tidak bisa dipungkiri keadaan ekonomi seorang guru yang mendapat gaji kecil dan juga tunjangan yang sedikit membuat mereka tidak merasakan suatu kesejahteraan begitu juga keluarganya.

Menurut Nawawi (1990) faktor-faktor yang mempengaruhi tinggi rendahnya efektifitas kerja salah satunya adalah faktor gaji atau upah, gaji tinggi akan meningkatkan efektifitas kerja seseorang.
Hal tersebut menyebabkan guru harus meluangkan waktu untuk bekerja sambilan agar mendapat tambahan pendapatan, selanjutnya kapasitas kelas yang melebihi standar dan kesehatan guru menghambat dalam meningkatkan motivasi dan kompetensi guru agama Hindu. Pada umumnya seorang guru agama Hindu maksimal mengajar enam kelas, di mana dalam satu kelas jumlah siswa yang banyak sehingga menyebabkan guru sulit membuat semua anak didiknya mengerti dan memahami apa yang disampaikan guru di depan kelas. Pada prinsipnya semua guru mempunyai tujuan yang sama dalam pembelajaran yaitu mentransfer ilmu yang dimiliki guru kepada anak didik. Namun tugas pokok guru agama Hindu jika dibandingkan dengan guru lain perbedaannya terletak pada penanaman disiplin yang berkaitan dengan akhlak dan budi pekerti anak didik (Perni, 2005: 27). Jika guru mengajar melebihi standar maka guru akan mengalami keletihan yang menyebabkan guru bekerja tidak baik dan tidak mempunyai gairah kerja.

Lebih lanjut ditambahkan oleh Suwimba Astawa (wawancara tanggal 7 Juni 2010) apalagi kurangnya perhatian orang tua terhadap pendidikan agama Hindu, di mana lebih ditekankan untuk mempelajari mata pelajaran yang diUN-kan dapat menyebabkan motivasi dan kompetensi guru Agama Hindu di Sekolah Dasar Saraswati 6 Denpasar kendor karena guru akan merasa bahwa pelajaran Agama Hindu dianaktirikan sehingga guru agama merasa kurang dihargai dibandingkan dengan guru mata pelajaran yang lainnya. Dan juga dengan kurang diperhatikannya pendidikan Agama Hindu dapat menyebabkan para anak didik malas mempelajari Agama Hindu. Dengan berkurangnya minat murid mempelajari Agama Hindu dapat menurunkan motivasi dan kompetensi guru untuk mengajar, karena akan mubasir guru mengajar Agama Hindu di depan kelas sedangkan para anak didik tidak menyimak dan mendengarkan dengan baik.

Selanjutnya sarana dan prasarana pembelajaran pendidikan Agama Hindu yang masih perlu ditingkatkan juga menjadi 
hambatan dalam meningkatkan motivasi dan kompetensi guru. Apabila sarana dan prasarana sudah memadai para gurupun bersemangat dan bergairah untuk melaksanakan tugas dan kewajiban dalam meningkatkan mutu pendidikan dan pengajaran di sekolah.

Senada dengan pendapat Perni (2005: 12) menyatakan bahwa dalam pengajaran Agama Hindu ditekankan pada tiga aspek yaitu tattwa, etika, dan ritual. Dalam hal ini memerlukan perangkat tertentu seperti sarana pemujaan, alat-alat pemujaan dan tersedianya buku-buku agama dan juga memerlukan lab untuk kepentingan proses belajar mengajar, khususnya lab upakara, sehingga dapat dikatakan pengelolaan sarana dan prasarana dengan baik dapat mendukung kegiatan pembelajaran dengan baik. Disamping itu padatnya kesibukan di luar jam mengajar yang dialami oleh Mardika (wawancara tanggal 7 Juni 2010) seperti mengurusi keluarga menjadi Humas di Sekolah Dasar Saraswati 6 Denpasar tentunya menyita waktu, tenaga dan pikiran yang nantinya dapat menghambat meningkatkan motivasi dan kompetensi guru.

\section{KESIMPULAN}

Berdasarkan pada penyajian data dan analisis hasil penelitian, seperti yang terurai pada Bab IV didepan yang mengacu kepada rumusan masalah dan tujuan penelitian maka secara umum dapat disimpulkan bahwa peran kepala sekolah dalam meningkatkan motivasi dan kompetensi guru Agama Hindu di Sekolah Dasar Saraswati 6 Denpasar sebagai berikut :

1. Peranan kepala sekolah bermanfaat sekali terhadap peningkatan motivasi dan kompetensi guru-guru Agama Hindu di Sekolah Dasar Saraswati 6 Denpasar. Peran kepala sekolah setidaknya dapat diamati dalam kegiatan pengawasan dan bimbingan dalam kegiatan pembelajaran. Apabila dicermati, tugas seorang kepala sekolah di mana penelitian ini dilakukan, bahwa lingkup kerja seorang kepala sekolah disamping mengadakan pengawasan secara periodik, juga memberikan bimbingan secara intens kepada para guru dalam proses belajar mengajar. Semua kegiatan itu bermuara pada upaya untuk meningkatkan motivasi dan kompetensi guru dalam melaksanakan tugas dan kewajibannya. Dengan demikian semakin efektif seorang kepala sekolah memberikan motivasi dan melakukan pengawasan kepada guru, maka semakin meningkat motivasi dan kompetensi guru tersebut.

2. Motivasi dan kompetensi guru agama Hindu di Sekolah Dasar Saraswati 6 Denpasar dalam melaksanakan tugas belajar mengajar di kelas penuh dengan semangat, tetapi ada pula hambatan-hambatan yang dihadapi dalam meningkatkan motivasi dan kompetensi guru di Sekolah Dasar Saraswati 6 Denpasar yakni tingkat kesejahteraan guru yang belum maksimal, kapasitas kelas yang melebihi standar, kesehatan guru, kurangnya perhatian orang tua terhadap pendidikan Agama Hindu, sarana dan prasarana yang masih perlu ditingkatkan dan padatnya kesibukan guru di luar jam mengajar yang dapat menghambat motivasi dan kompetensi guru.

\section{DAFTAR PUSTAKA}

Cahyono, B. TR. (1996). Manajemen Sumber Daya Manusia. Jakarta : Badan Penerbit IPWI.

Endraswara, S. (2006). Metodelogi Penelitian Kebudayaan. Yogyakarta: Gajah Mada University Press.

Gulo. (2002). Metodelogi Penelitian. Jakarta : PT Gramedia Widiasarana Indonesia.

Hamalik, O. (2001). Proses Belajar Mengajar. Bandung: Bumi Aksara. 
Hanafiah, N. (2009). Konsep Strategi Pembelajaran. Bandung : PT. Refika Aditama.

Kartika, N. G. A. (2018). Peningkatan Mutu Komunikasi Pemuda Yang Beretika Dan Cerdas Dengan Semangat Ajaran Veda. Jurnal Penjaminan Mutu, 4(1), 101-114.

Mulyana, R. (2004). Mengartikulasikan Pendidikan Nilai. Bandung: Alfabeta.

Mulyasa. (2005). Kurikulum Berbasis Kompetensi. Bandung : PT Remaja Persada Karya Bandung.

Palistini, N. L. A. (2018). Penerapan Metode Tutor Sebaya Untuk Meningkatkan Hasil Belajar Pendidikan Agama Hindu Pada Siswa Kelas III Sekolah Dasar Negeri 1 Sukadana. Jurnal Penjaminan Mutu, 4(1), 95-100.

Sardiman, A.M. (2005). Interaksi dan Motivasi Belajar Mengajar. Jakarta : CV. Rajawali.

Soehartono, I. (1995). Metode Penelitian Sosial. Bandung: PT Remaja Rosdakarya.

Sudarwan, D. (2009). Manajemen dan kepemimpinan Transformasional Kepala sekolah. Jakarta : Rineka Cipta.
Sujana, E. (2006). Kompetensi dan Motivasi Guru dalam Mewujudkan Suputra di SMAN 1 Bangli.

Suparmin. (2004). Motivasi dan Etos Kerja, Proyek Pembibitan Calon Tenaga Kependidikan, Biri Kepegawaian Sekretariat Jenderal, Depag RI. Jakarta.

Surakhmad, W. (1982). Dasar dan Teknik Reset Pengantar Metodologi Ilmiah. Bandung : Tarsito.

Sutrisno, H. (2000). Metodologi Reseach Jilid I. Yogyakarta: Andi.

Tilaar, H.A.R. (2002). Pendidikan untuk Masyarakat Indonesia Baru. Jakarta: Gramedia.

Uno. (2008). Teori-teori Belajar. Jakarta: Gramedia.

Wahjosumidjo. (1999). Kepemimpinan Kepala Sekolah : Tinjauan Teoritik dan Permasalahannya. Jakarta : Grafindo Persada.

Winardi. (2002). Motivasi dan Pemotivasian dalam Manajemen. Jakarta : Raja Grafindo Persada.

Zainun, B. (1981). Manajemen dan Motivasi. Jakarta : Balai Aksara 